\title{
AUDIOVISUAL AND SONG TRANSLATION OF INDONESIAN SUBTITLE IN SHELTER MUSIC VIDEO
}

\author{
Mohamad Irham Poluwa, Nafilaturif'ah \\ Universitas Airlangga (UNAIR), Surabaya, Indonesia \\ E-mail: mohamad.ham.p-2019@fib.unair.ac.id
}

Received: 2021-10-30

Accepted: 2021-11-23

\begin{abstract}
The current study aimed to find out the translation techniques applied by the translator in creating the Indonesian subtitles for the original lyrics of Shelter - a collaboration project of music video by Porter Robinson and Madeon, A1-Pictures and Crunchyroll uploaded on YouTube in 2016. The data were analyzed based on the audiovisual translation theory, especially the linguistics of subtitling, the translation technical procedures in the compared stylistics, and the choice in song translation. The study also applied qualitative approach which enabled the researchers to emerge data in descriptive way (in the form of words or pictures instead of numbers). Furthermore, the data were also in the forms of an audiovisual content. The study indicated that most of the lyrics were translated based on literal translation that was reflected by the equivalence of the source language and the target language. The audiovisual theory, particularly reduction theory was also applied in creating the subtitles. In addition, the subtitles were created without taking the music into consideration, meaning that the subtitles were devoted as a supplement or no more than another piece of the source text.
\end{abstract}

Keywords: Audiovisual Translation, Song Translation, Subtitles.

\section{Introduction}

The development of media, especially in the form of electronic media such as TV shows, music videos, as well as the internet platform like YouTube triggers the importance of audiovisual translation, most notably subtitling. According to Munday (2016), subtitling can be distinguished in several categories, namely interlingual subtitling, bilingual subtitling, and intralingual subtitling. Munday (2016) mentioned that interlingual subtitling could be 'open' or 'closed'. The 'open' subtitles means that the subtitles play an important role as an essential part of the film that are commonly found in various forms for the cinema and video. Meanwhile, the subtitles can be 'closed' when they are integrated to DVD, which means that the viewer can decide either they want to see the subtitles or not, and in which language. The bilingual subtitling is merely defined as the subtitles which are available in two languages at the same time. The intralingual subtitling is devoted for the hard hearing, increasingly a regulatory requirement.

As the internet platform grows rapidly, the number of movies, TV series, animation (anime), and any other types of shows that can be easily accessed online have also increased. The significant growth of this platform also increases the activity of creating 
Audiovisual and Song Translation of Indonesian Subtitle in Shelter Music Video, Mohamad Irham Poluwa, Nafilaturif'ah

subtitles. It can be seen based on the activity of subbing, especially interlingual subtitling as what is reflected by a study conducted by Guillot (2020) who concerned with film subtitles as a distinctive form of translation.

Besides, it is also proven by some studies related to fansubbing, such as Díaz-Cintas and Muñoz Sánchez (2006) who focused on audiovisual translation in the form of subtitles conducted by amateur translators (fansubs); Lee (2011) who explored the nature and implications of English fansubbing in anime; Josephy-Hernández (2017) who concerned with the graphemes translation in anime based on two different version: original and fansubbed versions; Rong and Omar (2018) who tried to explain fansub as a method of audiovisual translations; Puri and Pasaribu (2019) who examined translation strategies and translation acceptability in fansub of PUBG; and Wongseree et al. (2019) who examined the contemporary global media circulation on Thai fansubbing.

According to Díaz-Cintas and Muñoz Sánchez (2006), a fansub is subtitled version of anime (Japanese animation) that is produced and translated by fan(s). It is a tradition that exists as a result of the creation of the first anime clubs in the 1980s. Based on this definition, fansub in the early years is highly associated with anime or anime fans club. This is in line with Josephy-Hernández (2017) who argued that fansubbers worked almost exclusively with anime in the early years. However, fansubs nowadays are also related to any other audiovisual contents. It is because everyone (even relatively inexperienced users) who have internet connection and computer can easily create and insert subtitles into a film or TV shows using several software, such as Subs Factory, Aegisub and Subtitle Composer, which are available for everyone (Bogucki, 2009 as cited in Josephy-Hernández, 2017, p. 80). This is also in accordance with the argument that states fansubs or fansubbing can be defined as subtitling activities conducted by fans in the audiovisual content where language, image and music are integrated in a syncrhonized manner (Pérez-González, 2009, p.13 as cited in Wongseree et al., 2019, p. 1).

The significant trend of subtitling can also be seen in another internet platform like YouTube. As a popular media platform of the internet nowadays, YouTube provides numerous kinds of videos which may come based on various genres. One of most popular types of video on YouTube is the music video. Edmond (2014) argued that when the music videos were being sidelined by the music and television industries, at the same time, they were also instantly become a crucial element to online video aggregate and social media sites. Based on this statement, YouTube as an online sharing video platform, provides something that the television industries cannot offer.

There are many kinds of music videos uploaded on YouTube, which can also be based on different countries and different languages. In order to fulfill this gap, there is caption feature on YouTube video which enables the viewers to make or create their own subtitles. The viewer who makes the subtitles can also be regarded as an amateur translator or highly associated with fansubbing.

The current study focuses on Shelter, a collaboration project of music video in the form of short film (anime) created by Porter Robinson and Madeon with A1-Pictures and Cruncyroll. This video was uploaded on YouTube on October 18, 2016, and had been watched by more than 66 million views. This music video has an integrated subtitling to the video which is delivered in English. Furthermore, for the people who want to understand the meaning of the song in their own language, there is a caption feature that enables them to access the already made subtitle which is available in many languages. The objective of this 
study is to find out the translation techniques applied in the Indonesian subtitles, which can be seen based on audiovisual translation theory and song translation theory.

\section{Literature Review}

The present study was conducted by combining several theories of translation. The data were examined and analyzed based on the audiovisual translation theory, especially the linguistics of subtitling (Díaz-Cintas and Remael, 2007). Díaz-Cintas and Remael (2007) distinguished the linguistics of subtitling elements into several classifications, such as subtitling: translation as rewriting; text reduction; linguistics cohesion and coherence in subtitling; and segmentation and line breaks. Based on the classification, the study focused on text reduction.

Díaz-Cintas and Remael (2007) argued that there were three reasons why text reduction is required. First, the ability of the viewers or listeners to absorb speech is faster than their ability to read. Thus, subtitles must be able to provide them sufficient time in registering and understanding what is written at the bottom of the screen. Second, viewers must watch the action on screen, as well as listen to the soundtrack. Therefore, it is important to provide them enough time in reading, watching and listening at the same time. Third, subtitles are provided only to a maximum of two lines. Meanwhile, the time available, the reading speed applied to the subtitling, as well as the speed of the pronounced ST are factors that determine how much text should be contained in the subtitles. Considering how much time and space are available for a given translation, as well as ensuring that text reduction is needed, the translator or the subtitler has two options: eliminating irrelevant element for the sake of message comprehension, and reformulating relevant element as short as possible or required. Text reduction can be conducted in two different ways, namely partial reduction (through condensation and a more concise rendering of the ST) and total reduction (by doing deletion or omission of lexical items). In the process of translating, combining these two types of reduction is possible.

Condensation and reformulation can be conducted in two different ways, namely at word level (simplifying verbal periphrases; generalizing enumerations; using a shorter nearsynonym or equivalent expression; using simple rather than compound tenses; changing word classes; and short forms and contractions), and at clause/sentence level (Changing negations or questions into affirmative sentences or assertions, indirect questions into direct questions, etc.; Simplifying indicators of modality; Turning direct speech into indirect speech; Changing the subject of a sentence or phrase; Manipulation of theme and rheme; Turn long and/or compound sentences into simple sentences; Active sentences into passive or vice versa; Use of pronouns (demonstrative, personal, possessive) and other deictics to replace nouns, or noun phrases; and merge of two or more phrases/sentences into one).

Omissions can also be conducted in two different ways, such as at word level and at clause/sentence level. At word level, omissions is dictated by redundancy or relevance. Furthermore, some omissions have been considered language-bound. In translating from English, for instance, question-tags is not always necessary to be translated since the target language may not have them. Another example is the deletion of modifiers, such as adjectives and adverbs, which is also obvious to be done since their function only modifies the information carried by the verb or noun. In other words, even if they are eliminated in a certain context, the meaning of subtitles will not change and cause misunderstood to the viewers. Omissions at clause or sentence level sometimes are inevitable. For instance, when music is too loud that makes the dialogue is not audible or when some people are talking at 
Audiovisual and Song Translation of Indonesian Subtitle in Shelter Music Video, Mohamad Irham Poluwa, Nafilaturif'ah

the same time. Even though eliminating clause(s) or sentence(s) is not advisable, these kind of situations may happen, and therefore should be done.

Besides, the analysis also involved the translation technical procedures in the compared stylistics ( Vinay and Darbelnet, 1958 as cited in Molina \& Hurtado Albir, 2002, p. 499), which can be classified into two major classes, namely the literal translation - when both languages have structural, lexical or even morphological equvalence (i.e. borrowing - taking a word directly from another language; calque - translating and incorporating a foreign word or phrase into another language; and word for word translation), and oblique translation when it is not possible to do word for word translation (i.e. transpotition - a shift of word class, e.g. verb for noun; modulation - a shift in cognitive categories or in point of view; equivalence - using an utterly different phrase for the same situation, such as proverbs or idiomatic expressions; and adaptation - using different situation to convey the message).

In addition, since the data are in the forms of song lyrics, the choice in song translation proposed by Franzon (2008) will also be employed in analyzing the data. According to Franzon (2008), there are five choices in song translation, such as leaving the song untranslated; translating the lyrics but not taking the music into account; Writing new lyrics to the original music with no overt relation to the original lyrics; Translating the lyrics and adapting the music accordingly - sometimes to the extent that a brand new composition is deemed necessary; Adapting the translation to the original music.

There are several studies related to the present study. First is the study about the song translation study conducted by Suharto \& Subroto (2014). The objective of the study was to describe the equivalence of eclessial song lyrics, which comes from the content word, the sentences' meaning and their impact on church songs. The study employed qualitativedescriptive approach by involving music, language and interdiciline approach. The study revealed that the equivalence of the content word was diverse. Besides, there were only some content words which are completely translated. Furthermore, there were only some of the translated words were equivalent, while the rest of the words were either not equivalent or even not translated or lost.

Another study carried out by Puri and Pasaribu (2019) is also related to this study. The study was conducted as an attempt to examine strategies and acceptability of translation in PUBG fansubtitle. The study employed descriptive qualitative method in the form of document analysis. The study found that there were ten subtitling strategies applied in the translation, which consisted of transfer (40.9\%), taming (22.3\%), deletion (11.3\%), expansion (7.9\%), paraphrase $(5.8 \%)$, condensation $(2.7 \%)$, imitation $(2.7 \%)$, resignation $(1.2 \%)$, transcription (0.6\%), and decimation (0.6\%). Furthermore, the study also found 4 degree of acceptability, which consisted of Ideal-acceptable $(80,2 \%)$, acceptable $(3,7 \%)$, unacceptable (9.8\%), and failed (6.4\%). The study concluded that the most effective strategy of the Indonesian subtitle in PUBG fansubtitle is transfer. In addition, the translation was also considered acceptable since the acceptability degree of the fansubtitle reached $83.9 \%$.

\section{Research Method}

The current study employed qualitative approach in the process of examining the data. There were several reasons related to this consideration, which were also based on Creswell and Creswell (2018). First, qualitative approach emerges the data in a descriptive way, meaning that the data are reported in words or pictures instead of numbers (Fraenkel and Wallen, 1990 as cited in Creswell and Creswell, 2018, p. 278). Second, qualitative approach focuses on the process which is happening, and the product or outcome. Finally, the data 
used in this study are in the form of audiovisual data. The audiovisual data can be in the form of photographs, art objects, videotapes, website main pages, e-mails, social media text, and etc. In the current study, the source of the data was based on a music video in the form of short film, which can be freely accessed on YouTube.

The data of this study were the Indonesian subtitles of Shelter - a music video on YouTube in the form of short film. The short film was a collaboration project by Porter Robinson and Madeon with A-1 Pictures (a Japanese animation studio) and Crunchyroll (Anime Digital Network and Anime on Demand streaming services). The short film was uploaded on October 18, 2016 and consisted of 6 minutes and 6 seconds of duration. Besides, the video had been watched by $66,736,567$ viewers, and had gained 1,652,696 likes and 13,777 dislikes so far. The video consisted of a prologue, the song and an epilogue. The prologue of the video was a monologue delivered by Rin (voiced by Sachika Misawa), an anime character created and designed for the story of the music video.

The monologue was delivered in Japanese and translated into English in the form of subtitles. The subtitles for other languages, including Indonesian, were also available by activating the caption feature. The monologue started from 0:00 until 0:46. The song started playing at 0:49 until 4:42. The song was sung in English, and contained lyrics in English as well. The song was the main part of the short film. Shelter, the title of the video, also actually referred to the title of the song. This song was composed and sung by Porter Robinson and Madeon.

The last part is the epilogue, which consisted of monologue delivered by Rin in Japanese (similar to the prologue). The default translation provided in the video was in English. However, other languages were also available by activating the caption feature. The focus of the analysis was the song, which consisted of English lyrics and had been translated into Indonesian (by activating the caption feature). Thus, the analysis was conducted by applying the song translation analysis and audiovisual translation analysis since the song was in the form of music video and the translation was available in the form of subtitles.

There were several procedures that the authors had performed in collecting and analyzing the data. First, watching the entire video to determine the duration of each part of the video. Second, focusing on the Indonesian translation provided in the form of subtitle by activating the caption feature. Third, analyzing the Indonesian translation by applying the audiovisual translation (Díaz-Cintas and Remael, 2007), the translation technical procedures in the compared stylistics (Vinay and Darbelnet, 1958 as cited in Molina and Albir, 2002, p. 499-500), and compared it with the original lyrics of the song (the lyrics were obtained from the official website of this project: https://sheltertheanimation.com). Fourth, analyzing the song by applying the song translation analysis (Franzon, 2008).

\section{Results and Discussion}

As previously mentioned, the data of this study were the Indonesian subtitles of the song, which had been analyzed based on the combination of some theories, such as audiovisual translation (Díaz-Cintas and Remael, 2007), choice in song translation (Franzon, 2008), and translation technical procedures in the compared stylistics (Vinay and Darbelnet, 1958 as cited in Molina and Albir, 2002, p. 499-500). The table 1 presents the original lyrics of the song compared to the translation in the form of subtitle.

\begin{tabular}{|c|c|}
\hline English & Indonesian \\
\hline I could never find the right way to tell & Aku tak pernah bisa menyampaikannya dengan \\
\hline
\end{tabular}


Audiovisual and Song Translation of Indonesian Subtitle in Shelter Music Video, Mohamad Irham Poluwa, Nafilaturif'ah

\begin{tabular}{|c|c|}
\hline $\begin{array}{l}\text { you, } \\
\text { have you noticed I've been gone? } \\
\text { Because I left behind the home that } \\
\text { you made me, but I will carry it along. }\end{array}$ & $\begin{array}{l}\text { baik padamu, sadarkah kau bahwa aku telah } \\
\text { pergi? } \\
\text { Karena kutinggalkan rumah di mana kau } \\
\text { membesarkanku, tetapi aku akan tetap } \\
\text { melangkahkan kakiku. }\end{array}$ \\
\hline $\begin{array}{l}\text { Mm, it's a long way forward, } \\
\text { so trust in me. } \\
\text { I'll give them shelter like you've done } \\
\text { for me, } \\
\text { and I know I'm not alone, } \\
\text { you'll be watching over us. } \\
\text { Until you're gone. }\end{array}$ & $\begin{array}{l}\text { jalan yang kutempuh masih panjang, } \\
\text { jadi percayalah padaku. } \\
\text { Akan kuberi mereka naungan seperti yang kau } \\
\text { beri padaku, dan kutahu, aku tak sendiri } \\
\text { Kau akan terus memperhatikan kami } \\
\text { Hingga kau tiada. }\end{array}$ \\
\hline $\begin{array}{l}\text { When I'm older I'll be silent beside you, } \\
\text { I know words won't be enough. } \\
\text { And they won't need to know our } \\
\text { names or our faces, but they will carry } \\
\text { on for us. }\end{array}$ & $\begin{array}{l}\text { Saat aku beranjak dewasa, aku 'kan terdiam } \\
\text { disisimu, } \\
\text { aku sadar kata-kata saja takkan cukup. } \\
\text { Dan mereka tak perlu mengenali kita } \\
\text { Tapi mereka 'kan terus melanjutkan langkah kita }\end{array}$ \\
\hline $\begin{array}{l}\text { Mm, it's a long way forward, } \\
\text { so trust in me. } \\
\text { I'll give them shelter like you've done } \\
\text { for me, } \\
\text { and I know I'm not alone, } \\
\text { you'll be watching over us. } \\
\text { Until you're gone." }\end{array}$ & $\begin{array}{l}\text { jalan yang kutempuh masih panjang, } \\
\text { jadi percayalah padaku. } \\
\text { Akan kuberi mereka naungan seperti yang kau } \\
\text { beri padaku, dan kutahu, aku tak sendiri } \\
\text { Kau akan terus memperhatikan kami } \\
\text { Hingga kau tiada. }\end{array}$ \\
\hline
\end{tabular}

Table 1. The Indonesian Subtitle of the Original Lyrics of Shelter

The analysis can be started from the third line of the first stanza, "Because I left behind the home that you made me, but I will carry it along," which is translated to "Karena kutinggalkan rumah di mana kau membesarkanku, tetapi aku akan tetap melangkahkan kakiku." The pronoun it in this line actually refers to the home in the previous sentence. Based on this assumption, the authors think that "tetapi aku akan tetap melangkahkan kakiku" is not the correct translation for "but I will carry it along." Therefore, the author suggests an alternative translation of the sentence become "tapi aku akan membawanya pergi bersamaku."

This alternative translation is based on the modulation theory (from abstract to concrete and vice versa) proposed by Vinay and Darbelnet (1958) as cited in Molina and Albir (2002, p. 499-500), as well as the definition of the word home which can be either in concrete or abstract. The sentence "I will carry it along" does not mean that the person described in the song will carry "the home" in a concrete form since it is impossible and sounds illogical. Instead, the word home in this context can be interpreted as the person's knowledge or awareness; something that makes the person realizes that no matter how far he/she goes, there is always a place where he/she belongs to. It is something that can be considered a place to return. Besides, it can also refer to the family or memories that the 
person has shared with (his/her family). To put it simple, the word home in this context is something more abstract.

Another essential part of the lyrics is the third line of the third stanza, "And they won't need to know our names or our faces," which is translated into "Dan mereka tak perlu mengenali kita." This translation is based on linguistics of subtitling (Díaz-Cintas and Remael, 2007), especially in the use of a shorter near-synonym or equivalent expression which is also one of sub-classes in condensation and reformulation at word level. The literal translation of this line would be "Dan mereka tak perlu tau nama kita maupun wajah kita." However, the translator decides to translate the line into "Dan mereka tak perlu mengenali kita," in order to reduce the length of the subtitle. This is an effective way that the translator can do in order to create an understandable subtitle without even making it longer than it should be. The expression "mengenali kita" is effective enough to cover the entire meaning of "to know our names and our faces" since the length of the subtitle should not be more than two lines.

Finally, the translation had also been analyzed based on the five choices in song translation (Franzon, 2008). As previously mentioned, Franzon (2008) argued that the translation of the song was created based on five choices, namely, leaving the song untranslated; translating the lyrics but not taking music into account; writing new lyrics to the original music without overt relation to the original lyrics; translating the lyrics and adapting the music accordingly - sometimes to the extent that a brand new composition is deemed necessary; and adapting the translation to the original music. It can be said that the last three are decisions to make or create translation that can be sung. (Franzon, 2008) even complemented the last three choices with three layers of singability, such as a prosodic match, a poetic match and a semantic-reflexive match.

The Indonesian subtitle of Shelter is created without even concerning with the music. Thus, based on the 5 choices above, the Indonesian subtitle is made based on the second choice. As previously mentioned, the music video of Shelter had been watched by $66,736,567$ viewers, and had gained 1,652,696 likes and 13,777 dislikes. Therefore, Shelter can be regarded as one of popular music videos on YouTube even though it was uploaded five years ago. Based on this fact, it can also be assumed that the listeners/watchers are familiar with the song and its musical form (Franzon, 2008). In addition, Franzon (2008) argued that when the translator decided to choose the second choice, the role of the translations was just a complement to the original lyrics. In this case, the Indonesian subtitle is created due to the need of Indonesian people who do not really understand English, but still want to know the meaning of the lyrics.

\section{Conclusion}

There are several things that can be highlighted based on the identification of the Indonesian subtitles provided in the caption feature. First, the lyrics are mostly translated based on literal translation, particularly the word for word translation. It can be seen based on the equivalence from the source language and the target language. Second, the implementation of the audiovisual theory, particularly in the form of shorter near-synonym or equivalent expression, which is also one of sub-classes in condensation and reformulation at word level is accurate enough to produce the subtitle which is not long, but still can be understood by the viewers. The use of the expression "mengenali kita" Is effective to cover the meaning of "to know our names or our faces."

Third, the comprehension about the context of the source text is important in order to create the accurate translation. It is because instead of creating the effective and correct 
Audiovisual and Song Translation of Indonesian Subtitle in Shelter Music Video, Mohamad Irham Poluwa, Nafilaturif'ah

translation, the misunderstanding of the context will lead to the mistranslation as well. Besides, by providing the alternative translation to fix the mistranslation in the third line of the first stanza, the authors suggest to implement the modulation theory, specifically abstract for concrete and vice versa (Vinay and Darbelnet, 1958 as cited in Molina and Albir, 2002). Finally, the Indonesian subtitles for the original lyrics of Shelter can be regarded as a complementary elements, which is particularly devoted to the viewers from Indonesia who can enjoy the song in its original lyrics but still want to know the meaning of the lyrics. It can be seen based on the way it is translated which does not consider the music.

\section{References}

Creswell, J. W., and Creswell, J. D. (2018). Research design: Qualitative, Quantitative, and Mixed Methods Approaches. Sage publications.

Díaz-Cintas, J., and Muñoz Sánchez, P. (2006). Fansubs: Audiovisual translation in an amateur environment. Jostrans: The Journal of Specialised Translation, 6, 37-52.

Díaz-Cintas, J., and Remael, A. (2007). Audiovisual translation: subtitling. Routledge.

Edmond, M. (2014). Here we go again: Music videos after YouTube. Television \& New Media, 15(4), 305-320.

Franzon, J. (2008). Choices in song translation: Singability in print, subtitles and sung performance. The Translator, 14(2), 373-399.

Guillot, M. N. (2020). The pragmatics of audiovisual translation: Voices from within in film subtitling. Journal of Pragmatics, 170, 317-330. https://doi.org/10.1016/j.pragma.2020.09.015

Josephy-Hernández, D. E. (2017). The Translation of Graphemes in Anime in Its Original and Fansubbed Versions. TranscUlturAl: A Journal of Translation and Cultural Studies, 9(1), 78. https://doi.org/10.21992/t9rw5z

Lee, H.-K. (2011). Participatory media fandom: A case study of anime fansubbing. Media, Culture \& Society, 33(8), 1131-1147.

Molina, L., and Hurtado Albir, A. (2002). Translation techniques revisited: A dynamic and functionalist approach. Meta: Journal Des Traducteurs/Meta: Translators' Journal, 47(4), 498-512.

Munday, J. (2016). Introducing translation studies: Theories and applications. Routledge.

Puri, D. A. L., and Pasaribu, T. A. (2019). Pubg Fansubtitle: Strategies and Translation Acceptability. Journal of Language and Literature, 19(2), 126-139.

Rong, L. Z., and Omar, H. C. H. E. (2018). Understanding Fansub as One of the Audiovisual Translation Methods. KEMANUSIAAN: The Asian Journal of Humanities, 25(2).

Suharto, S., and Subroto, E. (2014). The equivalence of translated songs lyrics and their effects-the case of translated ecclesial songs. Harmonia: Journal of Arts Research and Education, 14(2), 131-139.

Wongseree, T., O'Hagan, M., \& Sasamoto, R. (2019). Contemporary global media circulation based on fan translation: A particular case of Thai fansubbing. Discourse, Context $\&$ Media, 32, 100330. 